\title{
Approaches to Community Development in Nigeria, Issues and Challenges: A Study of Ebonyi State Community and Social Development Agency (EB-CSDA)
}

\author{
Larry E. Udu ${ }^{1} \&$ Sunday O. Onwe \\ ${ }^{1}$ Department of Public Administration, Ebonyi State University, Abakaliki, Nigeria \\ Correspondence: Larry E. Udu, Department of Public Administration, Ebonyi State University, Abakaliki, \\ Nigeria. Tel: 234-803-744-1746. E-mail: lamaken.larryudu503@gmail.com
}

Received: August 18, 2015

Accepted: September 25, 2015 Online Published: January 26, 2016

doi:10.5539/jsd.v9n1p296

URL: http://dx.doi.org/10.5539/jsd.v9n1p296

\begin{abstract}
The study examined the activities of the Ebonyi State Community Based Social Development Agency (EB-CSDA), particularly on poverty reduction in the rural communities of Ebonyi State. Survey and content Analytical Approach were adopted. Data were extensively drawn from documentary papers, publications, oral interviews, direct observation and the use of structured questionnaire distributed to 400 sampled respondents from rural communities in the 13 LGAs of the State. Findings reveal that despite efforts of successive governments aimed at reducing poverty, the scourge has remained pervasive. EB-CSDA however, is rated high in the provision of micro-projects to the rural communities but its approach is group- targeted rather than on the individual poor. Consequently, the paper recommends among others that adequate background studies should be undertaken to understand the demographic characteristics of the rural communities to enable development agencies target their efforts on the real poor based on sufficient needs assessments of recipients.
\end{abstract}

Keywords: approach, poverty, community development, challenges, Ebonyi State

\section{Introduction}

What constitutes the major problem of community development inmost underdeveloped nations across the globe is perhaps, poor conceptualization of the term: "Community development". The definition of community is also controversial among scholars. The general lack of consensus in the conception of community gives rise to the quick perception of community as simply "rural". Hence, governments, particularly in Nigeria, perceive community development as essentially, rural development. Nkwede (2009), sees community as that collectivity, the members which share a common territorial area as their base of operation for daily activities. By this definition, a community may be both rural and urban; hence, a person can belong to many and different associations but cannot belong to or become a member of all communities at the same time.

According to Uma Lele (1995), over 80 per cent of the population of developing countries resides in the rural community. For this reason, community development efforts ought to be geared towards "improving the living standard of the mass of the low-income population residing in rural areas and making the process of their development self-sustaining". This understanding, informed the community development efforts of successive governments in Nigeria targeted in the rural communities. However, most of the community development efforts

failed to yield the desired results due to such factors as lack of background studies aimed at understanding the social and demographic characteristics of their target communities and groups, literacy level, pervasive poverty prevalent in those communities, hunger and disease; to mention but a few. This situation as argued by Udu (2014), has continued to result to a situation where there is visible mismatch between the community structure and the kind of empowerment programmes targeted at them.

Evidently, successive regimes in Nigeria have, at various periods initiated programmes aimed at addressing poverty, rural development and food security and their concomitant effects on the country. Such 2 programmes include: The Operation Feed the Nation and Green Revolution programmes of the military regime of Olusegun Obasanjo and Civilian regime of Alhaji Shehu Shagari (1979 - 1983), respectively. Others are the Directorate for Food, Roads and Rural Infrastructure (DFRRI) by the Babangida military administration (1985 - 1993); the Better Life for Rural Women and Family Support programmes by the wives of Babangida and Sani Abacha respectively; 
and the Family Economic Advancement Programme (FEAP) coupled with the very recent Subsidy Re-investment Programme (Sure-P) programmes. Most of these programmes had very laudable contents but implementation strategies proved to be mere window dressing and cosmetic as their impacts failed to reduce poverty in the country nor boosted the standard of lives at the grassroot.

Consequent upon the foregoings, particularly in view of the failure of these programmes to yield the desired results, the Ebonyi State government in collaboration with the United Nations Development programmes, embarked on the UNDP micro-credit scheme in the late 90s to address the critical issue of poverty and socio-economic development of its people. The abrogation of the UNDP programme gave rise to the establishment of the Ebonyi State Community-Based Poverty Reduction Agency (EB-CPRA) in 2005 to address poverty issues in the state. Thus, as poverty alleviation programmes in Nigeria, particularly in Ebonyi State, have not been believed to have been participatory, demand- driven, well targeted and originating from the people, EB-CPRA micro- projects were to be identified, selected and implemented by the Agency in collaboration with the target beneficiaries.

Be that as it may, as part of the 2005, 2007 Country Partnership Strategy (CPS), the Federal Government of Nigeria and the World Bank resolved to harmonize community development programmes funded by the world Bank in Nigeria. The process of the harmonization was to mobilize resources, optimally towards minimizing poverty rates in the country. As a result, the Local Empowerment and Environmental Management Project (LEEMP), and the Community Based Poverty Reduction Project (CPRP) were merged as a Social Development Approach.

Hence, the inception of the Ebonyi State Community and Social Development Agency which has the mandates of addressing poverty and socio-economic development of the people.

The specific objectives of this paper are to:

i. Ascertain the approaches to poverty reduction/community development in Ebonyi State;

ii. Examine the mandate of the Ebonyi State Community and Social Development Agency (EB-CSDA) in community development;

iii. Assess the contributions of EB-CSDA to community development in Ebonyi State vis-à-vis its avowed mandate; and

iv. Explore the challenges of community development in Ebonyi State with a view to proffering some remedial measures.

\subsection{Theoretical Foundation}

The paper is premised on the Institutional Approach propounded by Olisa and Obiuku (1992). According to the theory, there should be an institutional framework

for the planning and implementation of rural development programmes rather than the present adhoc strategy whereby agencies are created to handle particular situations and later become moribund when such programmes they were created to handle ends, or are scrapped by succeeding administrations. Rural people, according to this approach, need food, electricity, good healthcare, means of communication, facilities for social interaction, etc. Rural electrification, an improved sanitation, according to La-Anyene (2006), are also quite basic institutions in rural development, arguing that the latter is a measure of improved living standards while the former will arrest migration of the youths to the cities, since the events in the cities can be brought to them in the rural areas. They can use electrical appliances and, processing plants can be operated; they could also be better storage, heating and cooling and more attractive conditions for farming. The institutional approach therefore, advocates for a permanent institution which should have its presence permanently established in local government, to serve as permanent institution that will be responsible for monitoring, supervising, controlling and co-ordinating what happens at the grassroot with what happens at the top. The institutional approach ensures that development strategies are incremental such that efforts are improved upon progressively and outcomes are sustained by successive governments as well as development agencies.

\section{Conceptual Framework}

Darby and Morris in Nkwede (2009), defines community development as "an education which would raise levels of local awareness and increase the confidence and ability of community groups to identify and tackle their own problems. Ogunna (1989), believes that most writers on community development are influenced by their fields of study in their definition of the concept. Thus, some economists would consider it in terms of "encouraging some local material development". While some political scientists emphasize such value as "enlargement of individual freedom and mass democratic process". On the other hand, some Sociologists stress "group development and group action". 
The concept of community development has been used in different contexts and for different purposes by different scholars. A more comprehensive definition of community development has been expressed in the community development guidelines of the International Co-operative Administration of the United States cited in Ndukwe (2005). According to that agency, community development is "a process of social action which the people of a community organize themselves for planning an action, define their common and individual needs and problem; execute these plans with a maximum reliance upon community resources and materials from governmental and non-governmental agencies outside the community". From all these definitions, community development is not concerned with one aspect of life, but involves total community life and needs. Ideally, it involves all the members of the community, it requires their fullest participation in decision making and then decision implementation. People work together with or without extra support to shape their future and that of the community. Community development has to do with the elimination of such limiting circumstances of life as poverty, hunger, ignorance, sickness and fear, in a bid to bring about improvement in the standard of living of a people.

Equally, community development can be said to mean participation by the people themselves in efforts to improve their level of living and the provision of technical and social services in ways, which encourages initiative and self-help. Similarly, Uma Lele, in 1975, compiled what is popularly called the World Bank 'Bible' for developing countries. In a foreword to that book, Robert Mc Namara, the then president of the World Bank spelt out the rationale for the book - to raise productivity among the rural poor in developing countries (Lele, 1975). This task is urgent because according to him over 80 percent of the population of developing countries reside in the rural community. For this reason, Uma Lele, sees rural development as "improving the living standards of the mass of the low-income population residing in rural areas and making the process of their development self-sustaining" (Lele, 1975).

But as MC Namara observed, the more rural development packages are unfolded over time, the worse the conditions of the rural population became. Yet, nobody has stopped to ask the question why has every rural development plan failed to uplift the living standard of the rural population? For instance, the accelerated food programme of the Gowon administration, the Operation Feed the Nation of the Obasanjo regime and the Green Revolution of the Shehu Shagari era were all rural development packages unfolded in quick succession for the rural population of Nigeria. We are all living witnesses to how each of these packages fared (Udu, 2007).

How then, can community development be conceived? In the first place, it is imperative to view development as a multi-dimensional process of qualitative transformation of the populace. Thus, development is a societal as well as an individual phenomenon and cannot very easily, either analytically or concretely be limited to a specific locale. Changes in one area of the society invariably affect and sometimes stimulate changes in other areas either directly or indirectly. For instance, programmes to increase literacy level in the community may affect manpower demand and supply at all levels of the society. Development is a complex and pervasive process and should be seen as such. Seen from this perspective, it becomes unrealistic to speak of 'Community' 'Rural' 'Urban' development. It seems more appropriate to speak of an integrated national or societal development programmes as applied at the different levels of the society (Okokli, 2003). The current attempts to dichotomize and categorize development as 'community' and 'national' with different measuring rods, do not appear appropriate. Potentially, useful efforts are wasted in the bifurcation of what ought to be an integrated programme into mutually exclusive categories (Okoli, 2003). It is however, pertinent to point out that the above logic does not imply that the emphasis on 'community', rural or 'urban' development does not concern itself with national aspirations. It does, but implicit in the notion of community development for instance, is the idea of a better society.

However, more often than not, community development agents are swept off their guard by the imperatives of local problems and this leads to the elevation of 'community' development to an end in itself. When this happens, 'community' development assumes an independent status from 'national' development even though this has never been intended. But an emphasis on national development programmes starts off with the premise that societal or national betterment is the goal and by stressing application at different levels, it highlights the need for coordination and continuity. The development agent at the community level is constantly reminded of the need for harmonization of efforts with those at other levels. It is therefore necessary to stress national as opposed to community development.

\section{Methodology}

This study employed a survey research design. A survey design, according to Creswell (2013), provides a qualitative or numeric description of trends, attitudes or opinions of autonomous communities for instance in 9 Ebonyi State, World Bank Staff, Development Associations, Local Government Officials or some members of the academia by studying a sample of their respective populations. It generalizes from sample to a population so as to 
make inferences about the respondents in the study population aforementioned (Babbie, 1990). There are 96 autonomous communities in Ebonyi State, 88 Development Associations/Town Unions and 13 Local Government Areas. The entire population used for the study is 400 people. The respondents were selected, using stratified and simple random sampling techniques. The disproportionate stratified sampling technique which enables selection of equal number of cases from each stratum regardless of how the stratum is represented in the study area was used to distribute the 15-item questionnaire across the 13 local government areas in Ebonyi State.

The study used content and simple percentages for data analysis which was presented in statistical tables showing the performance levels. Pilot tests and the test-retest techniques were also used to determine instruments' validity and reliability.

4.

\subsection{Poverty in Ebonyi State: Social and Economic Context}

Poverty in Ebonyi State is a pervasive issue characterized by low levels of income and social deprivation. The federal office of statistics reports that 52.6 per cent Ebonyians are poor (Udu, 2009). The indicators for social sector development are favourable for Ebonyi State in general 10 and worse for the poor (EB-CPRA, 2009). Indicators of poverty are glaring everywhere in the state and manifest in worsening severity despite the vast human and natural resources, and the economic development potentials Ebonyi State is endowed with. A direct effect of poverty can be seen in virtual lack of such basic infrastructure and socio-economic amenities as good road network, health facilities, schools, portable water supply, etc. overt poverty shows up among the malnourished population, particularly among vulnerable groups, most often women and children.

Unemployment rate is acute, particularly in the rural areas where over 70 per cent of the population lives. In the United Nations Development Programme, UNDP (2002) Human Development Report, Enugu and Ebonyi "ranked low (0.466) in the Human Development Index (HDI); a combined measure of longevity (physical health, knowledge (education)", and income (purchasing power). This low expectancy is attributed to life expectancy at birth which "is estimated to be below 59.2 years for male and 60.7 years for female. Mortality rate for children under 5 is 191 per 1000 life births" (UNICEF Report, 1994). One-third of the state population is still without safe water and sanitation. Approximately, half of the population of rural dwellers obtains water from rivers. There is also high level of illiteracy.

Evidently, Ebonyi State as one of the South-East States (from the old Eastern Region), was one of the theatres of hostility during the civil war in Nigeria between 1967 - 1970. Consequent upon the vicious war, injustice and obnoxious post-war policies of past administration in Nigeria, economic 11 and social development of Ebonyi State was stifled. In addition, erosion has devastated most of the rural farmlands especially in the southern zones of the state; thus, rendering majority of the farmers unproductive and poor. Millions of naira would be required to check these ecological disasters and this, certainly, is beyond the financial capability of the state government (EB-CPRP, 2009). Similarly, the social service sector is in deplorable condition due to the hitherto marginalization of the people. Health facilities where available, are still ill-equipped; resulting to poor health-care services. There is also a resurgence of disease, especially the preventable ones like malaria, tuberculosis, STD/HIV/AIDS, guinea worm, as well as others like hypertension, diabetes mellitus; etc. All these are compounded by poor nutrition and high fertility rate of 7.0 (Udu, 2014). The above scenario clearly depicts Ebonyi state as one of the poorest states in Nigeria. Poverty, hunger and malnutrition exist in such a high-scale that they seem to defy political, economic and social efforts to eliminate them. It is against this background that Ebonyi State was selected by the Federal Ministry of Finance and National Planning Commission as one of the six pilot states in Nigeria for the phase II

Community-Based Poverty Reduction Project (CPRP). Be that as it may, investments in education, health and nutrition, etc, are necessary to minimize the scourge of poverty.

Similarly, investments in roads, water and environmental infrastructure is critical for the provision of reasonable access for these facilities to the poor rural dwellers. Unfortunately, the top-down management style and over centralized administrations in the past, created hurdles to managing development programmes; in addition to sever capacity limitations of the government and communities. For instance, where communities are unable to pull together their respective contributions and instead tend to resort to looking up to the government to support and partner them, coupled with lack of financies as well as technical aids. Therefore, improving the level of participation of communities in planning and execution of projects at the community levels and adopting a "bottom top" approach has been noted as an element of the development process (Udu, 2011). The approach, recognized that all community needs cannot be met all, at once. Hence, priority projects are identified by the communities themselves. Community participation in identification, preparation and financing, improves prioritization and efficiency. 
Unfortunately, it is recognized that even though a lot of poverty related data abound in Ebonyi State, they are not used effectively to enhance understanding of poverty phenomenon in the state. In the light of the foregoings, the Ebonyi State government has placed its highest priority on poverty reduction. This is based on the recognition that the benefits of economic growth have failed to trickle down to the majority of the population. The next section, would focus on these efforts by the state.

\subsection{Ebonyi State and Poverty Reduction/Social Development Programmes}

Consequent upon the foregoing poverty and socio-economic levels in the state, Ebonyi State government embarked on various programmes on 13 poverty reduction and social development. The first of these was in May 1997, when an agreement was reached for development cooperation between the UNDP and Ebonyi State government; the actual commencement of this programme was in May, 1999 (Abah, 2005). The programme essentially bordered on provision of micro-credit to groups and co-operative societies from communities in the state. The micro-credit scheme was designed for intervention at the state and local government and community levels with sole objective to create a pool of resources to be used as a revolving fund so as to provide the credit requirements of the beneficiary communities/group.

The UNDP document stated that the credit ceiling to any beneficiary group is N2,500,000 which actual amount of the loan is determined by an adequate assessment of the investments concerned, particularly the nature of the venture, the viability of the proposal, cash flow and business plan.

Evidently, as at 31st March, 2003, the UNDP through its micro-credit scheme, has disbursed an amount totaling N9,950,000 to community groups in Ebonyi State. The UNDP made some remarkable impacts in community skills development resulting to improvement in indigenous technology, youths empowerments, stimulation of commercial activities and ultimately improved standard of living at the community levels. Be that as it may, the UNDP micro-credit scheme was based on a 'top-bottom' approach; hence, did not originate from the people. Similarly, provision of credit was directed to groups rather than to the individual poor. Group initiative can undermine personal choices and preferences which is often on real need of a beneficiary. As a result of the observed flaw in the above approach, the Ebonyi State government on 23rd August, 2005, set up the Ebonyi State Community-Based Poverty Reduction Agency (EB-CPRA); with the mandate to select, appraise and finance the implementation of micro -projects which will: (i) support the rehabilitation and development of basic social and economic infrastructure, critical to the improvement and development of the economic and social conditions of the population, especially in the rural communities and poverty stricken areas of Ebonyi State; and (ii) improve the income earning capacity of poor people and household (Udu, 2014).

Hence, EB-CPRA Approach was to be particularly, demand-driven, well targeted and originating from the beneficiaries. Accordingly, its micro- projects were to be identified; selected and implemented by the agency in collaboration with the beneficiary communities. EB-CPRA is rated high. Its success in the state may be ascribed to: autonomous in implementing its projects and the fact that it gave room for the involvement of civil Society as board members; an improved motivation of the staff who were paid private sector salaries; and above all, the fact there were no undue external interferences basically from politicians because, the projects were perceived to be autonomous from the State.

However, in 2007, a harmonization policy that saw the Empowerment and Environmental Management Project (LEEMP) and the Community Based Poverty Reduction Projects (CPRP) merged as a social development approach, and, this resulted to the Ebonyi State Community and Social Development Agency (EB-CSDA).

\subsection{The Mandates of the EB-CSDA}

The overall goal of the CSDP according to its Project Operation/Implementation Manual (2011): "is to improve access to services for Human Development (HD)". To achieve this laudable goal, the Project Development Objective (PDO) "is to support empowerment of communities and local government authorities for sustainable increase access of poor people to improved social and, natural resource infrastructure services".

Specifically, the avowed mandates of the CSDA are to:

(i) Empower communities to plan, part-finance, implement, monitor and maintain sustainable and society inclusive multi-sectoral micro- projects;

(ii) Facilitate and increase Community- LGA partnership on HD -related projects;

(iii) Increase the capacity of LGAs, State and Federal Agencies to implement and monitor CDD policies and interactions; and, 
(iv) Leverage Federal, State and Local Government resources for greater coverage of CDD interactions in communities (POI. Manual, 2011).

\subsection{Assessment of EB-CSDA Contributions to Community Development}

In pursuit of its avowed mandates as highlighted above, the agency has embarked on a number of micro-projects, some of which has direct 16 impacts on the socio-economic lives of the target population. For instance, the agency has been involved in micro-projects in the sectors of education, health, water, rural electrification, transport, socio-economic as well as Environment and natural resources. Some of the micro-projects in these sector-specific areas includes: classroom blocks, health centres, drilling of bore-holes, rural electrification, roads/bridges, market stalls, civic/skills acquisition centres and construction of VIP toilets. To ensure the success of projects undertaken by the agency, a participatory approach was adopted. Hence, the beneficiary communities/group identified and selected projects of their choice, paid a 10 per cent counter-part fund of total project cost while the agency, approved, monitored implementation/execution on stage-by-stage basis to ensure compliance to rules and standard. This collaborative approach indeed, led to successful completion of numerous projects on schedule. A summary of EB-CSDA executed projects as at 31st December, 2015 are shown in table 1 below.

Table 1. Summary of approved/funded micro-projects by sector

\begin{tabular}{lllllll}
\hline S/N & Sector & $\begin{array}{l}\text { Approved } \\
\text { mps }\end{array}$ & $\begin{array}{l}\text { Completed } \\
\text { mps }\end{array}$ & $\begin{array}{l}\text { On-going } \\
\text { mps }\end{array}$ & $\begin{array}{l}\text { Yet } \\
\text { commence }\end{array}$ & $\begin{array}{l}\text { to } \\
\text { Disbursement }\end{array}$ \\
\hline 1 & Education & 42 & 32 & 05 & 04 & $157,721,148.46$ \\
2 & Health & 08 & 06 & 01 & 01 & $30,288,746.23$ \\
3 & Water & 62 & 60 & 01 & 01 & $157,631,134.50$ \\
4 & Rural Electrification & 47 & 46 & 01 & 0 & $282,020,888.70$ \\
5 & Transport & 45 & 44 & 01 & 0 & $173,155,183.70$ \\
6 & Socio-economic & 38 & 29 & 05 & 04 & $165,535,288.155$ \\
7 & Environmental \& Natural & 06 & 05 & 0 & 01 & $6,905,840.00$ \\
& Resources & & & & & \\
\end{tabular}

Source: Ebonyi State Community and Social Development Agency (EB-CSDA) 2003.

One observes from the above table, that out of a total approved 248 micro-projects, the agency has successfully completed $222(89.52 \%)$. A closer examination of the figures also reveal that water has the greatest number of approved and executed projects (62/60); followed by rural electrification (47/46) while transport with 45 approved and 44 executed projects as well as education with 42 approved projects and 32 completed projects came third and fourth respectively, in the priority list. Some of these observations deserves some further comments. Considering the scourge of water-borne diseases such as guinea worm, cholera, typhoid fever,

which have hitherto been endemic in most rural communities of the state, the preponderant attention on provision of portable water supply is quite understandable. However, for education to rank fourth in the priority scale with even the least number of completed projects comparable to total approved figure is unexplainable; moreso, in a state that has been ranked among the educationally disadvantaged states in Nigeria - the total expenditure figure as shown in the table notwithstanding. The same is true of health and environment which have a sort of correlation with each other in eliminating preventable diseases. However, it can be argued that, due to the prevalent poverty in the state, 18 visa-a-vis its lean financial resources, every project, irrespective of the sector from where it derives, appear to be a priority at the same time.

Table 2, is further presented to show how the disbursement $(\mathrm{N} 973,258,229.61)$ shown in table 1 above was carried out at the 13 local government areas of the state and the rural communities. 
Table 2. Disbursement to micro-projects by LGAs as at $31^{\text {st }}$ December, 2013

\begin{tabular}{llllll}
\hline S/N & LGA & $\begin{array}{l}\text { NO } \\
\text { COMMUNITIES } \\
\text { FUNDED }\end{array}$ & $\begin{array}{l}\text { OF } \\
\text { AMOUNT DISBURSED }\end{array}$ & $\begin{array}{l}\text { \% } \\
\text { OISBURSEMENT }\end{array}$ \\
\hline 1 & Abakaliki & 12 & $96,901,936.10$ & 9.95 \\
2 & Afikpo North & 07 & $54,012,588.60$ & 5.54 \\
3 & Afikpo South & 08 & $60,652,275.24$ & 6.23 \\
4 & Ebonyi & 08 & $74,951,662.80$ & 7.70 \\
5 & Ezza North & 07 & $66,252,256.50$ & 6.80 \\
6 & Ezza South & 08 & $82,125,932.20$ & 8.43 \\
7 & Ikwo & 10 & $88,358,673.49$ & 9.07 \\
8 & Ishielu & 07 & $61,070,211.29$ & 6.27 \\
9 & Ivo & 04 & $32,867,253.40$ & 3.37 \\
10 & Izzi & 10 & $98,528,883.70$ & 10.12 \\
11 & Ohaozara & 10 & $96,856,231.30$ & 9.95 \\
12 & Ohaukwu & 13 & $116,609,993.99$ & 11.98 \\
13 & Onicha & 06 & $44,075,331.00$ & 4.52 \\
& Total & 110 & $973,258,229.61$ & 100 \\
\hline
\end{tabular}

Source: EB-CSDA (2003).

Ebonyi State Community and Social Development Agency (EB-CSDA), is rated high in both development objectives and implementation performance. Over 80 per cent of respondents are unanimous that the agency has lived up to its avowed mandate. The Federal Government of Nigeria (FGN) and the World Bank (WB) are equally in agreement on the desirability of the community development approach in the overall strategy for poverty reduction in the country.

However, EB-CSDA's approach to poverty reduction and social development at the grassroot, like its predecessors' (EB-CPRA and the UNDP micro-credit schemes) are still group-targeted. The essential and indeed, all-pervading fact is that, poverty resides more on the individual and group initiative in selecting community projects, undermine personal preferences.

\subsection{Challenges of Community and Social Development Programme}

Issues of institutional capacity, accountability and transparency are critical to sustainable development in Nigeria. Public institutions in the country are not efficient enough to address the challenges of poverty reduction despite the numerous programmes initiated by successive governments in Nigeria in this direction. Pervasive poverty in the country is evidenced by the fact that 55 per cent of the country's population live on less than US\$1 per day (CPS) and 60 per cent of the 75 million of Nigerians particularly, those at the rural communities are wallowing in abject poverty. (EB-CSDA, 2013). Furthermore, Nigeria is faced with the daunting task of achieving growth rates of greater than 5 per cent in the non-oil economy in order to significantly reduce poverty rates. Hence, poverty and poverty reduction in the country poses enormous challenge to community and social development programmes. The majority of Nigerian citizens are poor; the community and government machinery are in dire need of capacity improvement and the provisions of the vision 20:20:20 and its attendant country partnership strategy culminate to further challenge the commitment of the Agency. The challenges of CSDP are discussed in detail in the following paragraphs/sub-headings. In spite of the huge amount of money disbursed to micro-projects in various communities of different Local Governments of Ebonyi State, the per-capita income and Human Development Index of the people still remain low. This may be attributable to the distribution approach. It is believed that training and development of individuals within the communities in various Local Governments would have been the fundamental step so that the money earmarked for the programme can be disbursed to individual beneficiaries. It is the story view of this paper that this approach will be more sustainable.

In situation where disbursement is made for micro-projects based on communities may not be sustainable and grass-root enough since the elites among the various communities may scuttle the entire arrangement. 
Poverty in Nigeria, as pointed out earlier in this study, is a pervasive issue; particularly in the rural communities where over 80 per cent of the country's population reside. Evidently, there are low levels of income and acute social deprivation. At the national level, social and economic indicators are poorer that the United Nations recommended standard talkmore of the rural communities. For instance, Ebonyi State has been identified as one of the poorest states in the country; as well as one of educational backward states. Available statistics show that over 70 per cent of youths that hawk at traffic hold-ups in big cities in Nigeria are Ebonyians. The same is true of those who do menial jobs at construction sites, house-helps, gardeners and messengers in some low profile hotels and eating houses. Unfortunately, most of these youths are otherwise brilliant but cannot afford the 'luxury' of education due to poverty. The challenge of the agency in this regard is even exacerbated by the fact that its focus is not on tertiary institutions. Many undergraduate Ebonyians, particularly in the only state owned University, sponsor themselves at school to obtain a University degree. With rising cost of University education in Nigeria, there has been enormous records of undergraduates dropping out from the University because they cannot afford the prescribed fees. The concomitant effect of all these in a state hitherto characterized as educationally backward can be better imagined than expressed as over $80 \%$ of University undergraduates of Ebonyi State origin have dropped from school during the last seven years due to increase of school fees. Be that as it may, successive administrations in Nigeria, particularly in Ebonyi State have embarked on numerous projects aimed at reducing poverty particularly at the rural communities in the country. These include: road construction, bridges/culvets, provision of health facilities, portable water through sinking bore-holes and even

free and compulsory primary and secondary education - by the Sam Egwu regime which was not sustained after his administration. However, the aforementioned projects failed to yield the maximum benefits to the perceived beneficiaries due to lack of proper focus and direction. Hence, many of the supposed beneficiaries did not even know that such projects existed let alone feeling the impacts. In otherwords, the purported target group/communities were not given any sense of belonging; hence, the projects had low rate of survival and lacked accountability. The vicious circle of poverty has continued to exist because, even while the poor communities had the potentials to participate in project identification, selection and implementation, such critical factors like skill and funds were 22 glaringly lacking. The overall effect is that, the poor gets poorer increasingly, while the government and perhaps, development agencies, appear to be deceived by the volume of media publicity in support of such programme/projects.

(ii) Local Government and Human Development

Consequent upon the 1976 Local Government Reforms in Nigeria, more roles were assigned to the Local Government and presently, the number of local government areas in the country increased to 774, with clearly delineated functions and responsibilities. The relationship between the local government and the state as well as the federal government is also specified in the 1999 constitution. The constitution assigns specific duties to the LGAs in recognition of the fact that local governments are closer to the grassroot; hence, ought to exercise sufficient autonomy to be able to discharge its constitutional roles and responsibility to the grassroot. However, the constitutional autonomy of LGAs in Nigeria, are merely in principle;

in practice, this autonomy has been restricted by higher levels of government not only through statutory means but also by limitations on their discretion in making and extending their budgets and in control of their personnel in the form of guidelines having the force of law periodically issued by state governments as policy (EB-CSDA, 2013).

Again, the Level of autonomy is incumbered by the fact that local governments direly depend on renue from the central government-a situation thatis further worsened by the level of poor revenue generation at these levels of government. In general, most projects at the LG are solely sponsored by government or donor agencies with little or no involvement whatsoever of the grassroots. As a result of lack of requisite skills, proper planning and coordination, there are still evidences of duplication and multiplicity of projects despite the pitiable states of resources at their disposal. The readiness of some LGAs to work with the communities notwithstanding, most of them have poor understanding of poverty- focused efforts, thereby, posing more challenge to the development agency.

(iii) State Government and Local Development

Evidently, local governments have some commitment to community- based poverty reduction over the years. However, existing side by side of the observed commitment are the general lack of capacity to design and 
implement multi-sectoral programmes. This is because, state governments are used to expenditure allocated along sectoral lines. It has also been noted that state government pay insufficient attention to monitoring and evaluation of projects to ensure success and sustainability as well as needs assessment which is so central to programming and planning- all these are lacking in the project cycle of state governments. The implication of this is that, while resources for development may be available to state governments, there still exist a wooping capacity gap at that level of government.

(iv) Linkage of CSDP with Development Priorities of Government

The design of CSDP corresponds with the development priorities of both government and other development agencies especially in the areas of poverty reduction, employment creation and wealth generation (EB- CSDA, 2011). There is also a link between vision 20:20:20 and CSDP projects. For instance, the cardinal objective of vision 20:20:20 as cited in EB-CSDA (2011) is:

the pursuit of a strong, virile and broad-based economy with adequate capacity to absurd externally generated shocks. This would be anchored on the creation of a national economy that has highly competitive, responsive to incentives, private sector led, broad-based, diversified, market oriented and open but based on internal momentum for its growth. It is within this context that the CSDP is linked with the current national comprehensive framework for reform, growth and poverty reduction.alongside related MDGs programmes which essentially border on core economic, political and social variables to speed up development of backward African nations. (EB-CSDA, 2011).

All these pose, various degrees of challenges to community and social development programmes, particularly, in Ebonyi rural communities. This is due to its low level of institutional and human capacity development. A cursory look at the foregoings reveal that institutional and individual poverty predominate all other factors that challenge the agency in Ebonyi State. For this reason, it becomes imperative to examine the causes of poverty particularly, in the rural communities of Nigeria.

\subsubsection{Causes of Poverty}

Apparently, there is a slim disagreement among scholars and economists on the causes of poverty as against the difficulty of arriving at a consensus definition of poverty. Scholars agree on the basic factors responsible for the prevalence of poverty such as macroeconomic distortions, effects of globalization, governance, corruption, debt burden, low productivity, unemployment, high population growth rate and poor human resources development (Eko, et al, 2013). These factors may differ from country to country depending on the level of economic development

and related peculiarities. While the CBN (1999), grouped the causes of poverty into two categories: "low economic growth and market imperfections"; the World Bank (2001), stated that "one route of investigating the causes of poverty is to examine the dimensions highlighted by the poor, such as:

(a) Lack of income and assets to attain basic necessities of life - food, shelter, clothing and society; and

(b) Sense of voicelessness in the institution of state and society; and

(c) Vulnerability to adverse shocks, linked to an inability to cope with them".

However, the National Bureau of Statistics (1996), Socio-Economic profile of Nigeria was definite in categorizing the causes of poverty in Nigeria to include: lack of access to:

i. $\quad$ Employment opportunities for the poor;

ii. Land and capital by the poor;

iii. Markets for the goods and services that the poor can sell;

iv. Education, health, sanitation and water services;

v. The destruction of the national resources endowments which has led to reduced productivity of agriculture, forestry and fisheries;

vi. Inadequate access to assistance by those who are the victims of transitory poverty, such as drought, floods, pests and war; and, 
vii. Inadequate involvement of the poor in the design of development programmes.

The causes of poverty in Nigeria, especially in the rural communities of Ebonyi State are inexhaustible. However, Edoh, 2003 cited in Nkwede, 2014, argued that, imperatively, in Nigeria, the practice of relative wage income hypothesis, where jobs are evaluated in the basis of job content and wages are paid accordingly is largely not applicable; rather, government incomes at all levels are shared among politicians, political cohorts and dubious contractors. The study reveals that over $80 \%$ of Ebonyians particularly at the rural communities are living in abject poverty. The foregoings are views on causes of poverty; but the factors responsible for pervasive poverty, particularly in the rural communities of Ebonyi State are captured in the table below.

Table 3. Respondents' opinions on factors responsible for pervasive poverty in Ebonyi State

\begin{tabular}{llll}
\hline S/N & OPTIONS & RESPONSES & $\%$ \\
\hline 1 & Weak institutions/poor governance & 76 & 21.11 \\
2 & Improper needs assessment & 52 & 11.44 \\
3 & Corruption of government/Agency officials & 47 & 13.06 \\
4 & Unstable economy (inflation \& high cost of living) & 71 & 19.72 \\
5 & Unstable sources of income & 74 & 20.56 \\
6 & Poor educational background & 40 & 11.11 \\
& Totals & 360 & 100 \\
\hline
\end{tabular}

Source: Udu's field survey, 2015.

\section{Conclusion}

It has been noted that over 80 per cent of the population of developing countries reside in the rural communities. For this reason, rural/community development is conceived "as improving the living standards of the mass of the low-income population residing in rural areas and making the process of their development, self-sustaining" (Lele, 1975). It therefore, makes sense to state that for any community development effort to be worthwhile and ultimately yield the desired outcome, the critical issue of rural poverty ought to predominate all other considerations. In view of this, successive governments, particularly in Ebonyi State, over the years, have embarked on community and sound development/poverty reduction programmes to address the issue of poverty in Ebonyi State rural communities.

Most of these programmes were indeed laudable but unfortunately failed to have tackled poverty issues frontally as poverty continues to assume a sort of pervasive posture in the state; the involvement of the beneficiaries in project identification, selection and implementation, notwithstanding. The evasive nature which poverty in the state appear to have assumed despite government and donor agency interventions are attributable to poor background studies on the demographic characteristics of the rural communities which often, have resulted to a kind of mismatch between poverty reduction efforts and the actual needs of the beneficiary communities. No doubts, the Ebonyi State Community- Based Community and Social Development Agency (EB-CSDA) has made a significant positive impact on poverty reduction and in improving the living standard of the rural communities despite the challenges of pervasive poverty in the areas. The position of this paper therefore, is that efforts aimed at poverty reduction and social development of the rural communities should be geared less on the institutions and group and more targeted on the individual. This is because, poverty reside more on the individual and, group initiatives are capable of undermining personal choices, preferences and real needs of the specific individuals. Hence, a result-oriented development programme is that, that makes man the beginning, the centre and the end its efforts.

\section{Recommendations}

Based on the outcome of this study, the following recommendations are proffered so as to reposition the Ebonyi State community and social 29 development agency to breast up with its challenges and thus address the identified core causes of poverty in the rural communities.?

- Extensive background studies should be sponsored and infact, undertaken to understand the demographic characteristics of the rural communities before any programme is implemented. Hence, adequate needs 
assessment is imperative to determine the actual needs of the poor and programmes should be targeted more on the individuals rather than on any group. ?

- Government and the poverty reduction agencies should embark on periodic workshops and seminar to conscientize the public, particularly the rural poor on its programmes and activities; such orientation exercises should sufficiently involve the beneficiary communities in all critical stages of the programmes such as planning and implementation stages.?

- Good governance and transparency should form the basis of all poverty and social development programmes. In this way, the strategies as may be adopted by government and the agency, would be well selected, focused and cost-effective so as to achieve optional results. ?

- A well functional monitoring mechanism should be established to ensure effective and efficient programme implementations. There should also be periodic evaluation of programmes to enable the agency ascertain its progress/achievement based on set objectives and standard. Since agriculture is the major occupation of the people at the rural communities, government should urgently strategize on policies that would assist in boosting agricultural produce, such as mechanized farming, improved seedlings, soft loans to the farmers and provision of fertilizer on affordable rates to the rural farmers. This would assist in stabilizing the major source of income of the rural poor which is subsistent farming.

- There is also the need to embark on aggressive job creation to reduce the level of unemployment among the youths in the country. Unemployment rate has been on the increase over the years and, this is indeed worrisome in a country aspiring to reduce the poverty rate of its citizens.?

- Equally imperative is the need to diversify the economy from the prevalent dependency on oil. Diversification of the economy would improve the dwindling foreign exchange rate, reduce inflation and improve the value of financial resources at the disposal of the citizens; by so doing, poverty would be reduced and the standard of living of the rural communities would be improved significantly. ?

- Skill acquisition programme should also be encouraged among individual in various rural communities.

\section{References}

Abah, E. O. (2005). United Nations Development Programme And Sustainable Human Development in Nigeria A Study of Ebonyi State; Ph.D Thesis, UNN.

Babbie, E. R. (1990). Survey Research Methods (2nd ed.). Cengage Learning.

CBN. (1999). Nigeria's Development Prospects: Poverty Assessment and Alleviation Study. CBN in Collaboration with the World Bank, p.3.

Community And Social Development Project Manual. Central Bank of Nigeria. (CBN, 2010). Annual Report and Statement of Account, December 2003, p. 76.

Creswell, J. W. (2013). Research Design: Qualitative, Quantitative and Mixed Approaches (4th ed.). Sage Publications.

Edoh, T. (2003). Poverty and the Survival of Democracy in Nigeria. Nigerian Journal of Political Administrative Studies, 1(4).

Eko, S. A., Utting, C. A., \& Udousoro, L. E. (2013). Tackling Poverty In Nigeria: An Appraisal of the National Directorate of Employment, (NDE) Programme in Cross River State. Multi-Disciplinary Journal of Research and Development Perspectives, 2(1), 1-16.

National Bureau of Statistics. (1996). Socio-Economic Profile of Nigeria, NBS 1996, NBS, Lagos: p. 109.

Nkwede, J. O. (2014). Approaches for Poverty Alleviation and Sustainable Development in Nigeria: A Study of Ebonyi State Community Based Poverty Reduction Agency (EB-CPRA). International Journal of Social Sciences Studies, 2(1), 153-163.

Nkwede, V. I. (2009). Community Development and Urbanization In Nigeria (Theories and Applications). Onitsha Chambers Books Ltd.

Okoli, F. C. (2003). Politics of Development and Underdevelopment (Theories of Development). Nsukka; Tpomost Press \& Business Centre.

Operation Manual for Community Project Implementation Committees and Community Project Monitoring Committees. EB-CSDA. (2011).

Udu, L. E. (2007). The Implications of the Creation of Additional Development Centres for Community 
Development in Ebonyi State. Nigerian Journal of Business, IV(1), 98-107.

Udu, L. E. (2009). Human Capacity Development in Nigeria: A Historical and Analytical Perspective. EBSU Journal of Sociology, 3, 65-76.

Udu, L. E. (2011). Poverty Alleviation Strategies in Nigeria: The Ebonyi State Experience. EBSU journal of Society, 1(4), 76-82.

Udu, L. E. (2014). Human Capacity Building In Selected Local Government Areas of Ebonyi State - The Role of Non-Governmental Organizations (NGOs) and Development Agencies (2000-2008). Journal of Business and Management, 3(1), 25-41. Retrieved from http://www.todayscience.org EB-CPRP

UNDP. (2002). Human Development Report, Millennium Edition. Lagos: UNDP.

World Bank. (2001). World Development Report 2000/2001: Attacking Poverty. New York: Oxford University Press Inc.

\section{Copyrights}

Copyright for this article is retained by the author(s), with first publication rights granted to the journal.

This is an open-access article distributed under the terms and conditions of the Creative Commons Attribution license (http://creativecommons.org/licenses/by/3.0/). 